\title{
Responsabilidade Civil. Os Novos Conceitos Indenizáveis no Projeto Reale ${ }^{(*)}$
}

\author{
Arthur E. S. Rios
}

(Universidade Federal de Golás)

\begin{abstract}
SUMARIO: 1.) O simples risco da atividade da pessoa e suas conseqữencias danosas para terceiros, 2.) $O$ ato prejudicial do abúlico e sua obrigação de indenizar. 3.) A presença maior da regra da necessidade da vitima, diante da possibilidade maior ou menor do agente do dano. 4.) $O$ autor sem culpa e o terceiro culpado, mas não agente do đano. 5.) Os novos parâmetros econômicos e socials do agir responsável. 7.) O novo conceito de cumprimento de obrigação e a divida de valor e não de dinheiro. 8.) A gravidade do ato e não a extensão do dano como medida indenizatória. 9.) O puro dano moral inđenizável por eqüidađe. 10.) A ofensa aos «direitos da personalidades $\Theta$ os cálculos indenizatórios. 11.) A queda do subjetivismo $e$ individualismo na nocão de culpa, diante da ascensão do objetivismo e do direito social na noção de mera causa. 12.) A responsabilidade do Estado.
\end{abstract}

\section{O Simples Risco da Atividade da Pessoa e Suas Consequiências Danosas para Terceiros.}

O art. 159 do Código Civil de 1916. . .

«Aquele que, por ação ou omissão voluntária, negligência ou imprudência, violar direito ou causar prejuízo a outrem, fica obrigado a reparar o dano».

... fixa um princípio de que o ato indenizável nasce na vontade de seu autor, na faculdade do querer, no seu discernimento de e para 0 fato.

É um dispositivo de «responsabilidade subjetiva» (da pessoa em si e por si mesmo), pois parte da CULPA como regra-meio para se chegar ao fim que é OBRIGAÇÃO DE REPARAR. Não se olvidam as exceções em partes outras e nas posições doutrinárias e jurisprudenciais divergentes em nossos dias, no direito brasileiro.

E as exceções não são poucas (1.521/7/9), dando na PARTE ESPECIAL DO CóDIGO uma leve tendência objetiva, daí se pensar numa intermediação entre o SUBJETIVO e o OBJETIVO ou uma mistura de

(*) Conferência pronunciada na Faculdade de Direito da Universidade de Goiás no "Seminário Sobre o Projeto Reale" aos 30 de abril de 1985. 
água com azeite... que a SÚMULA 341 denomina de CULPA PRESUMIDA, ou seja que não se prova, mas se suspeita!. . .

O conceito de presunção legal é o mesmo de suspeitar, presumir ou imaginar, o que sempre nos pareceu, datíssima vênia dos doutos: uma solução simplista para a magnitude dos julgamentos por parte do Estado. O que se pode presumir é, ao contrário, a ausência de culpa do agente do dano ou seu estado de virtude e nunca a culpa ou seu estado de vício ou pecado do querer. Presume-se o positivo e prova-se o negativo, isto é, de início, dá-se um crédito à integridade e não o contrário.

A teoria da CULPA PRESUMIDA não nos convence, no campo do direito, pelas mesmas razões que repelimos o «mal presumido», como essência existencial da pessoa humana. A culpa ou ausência de culpa, o mal e o bem, como fatores de julgamentos e juizos, só podem existir, objetivamente, com base em provas e não em presunções, sempre quando possivel.

A posição de CULPA PRESUMIDA também não se sustenta, pois é de irritante conservadorismo e apego a uma idéia já não confortáve] na fase do DIREITO SOCIAL do Século XX. Está encerrada a fase do individualismo em todos os campos da ciência! Foram duas grandes guerras mundiais e uma gama enorme de problemas sociais, que acabaram trazendo benefícios no desenvolvimento do pensamento político, social e jurídico, chegando nas OBRIGAÇÕES DE REPARAR DANOS a uma necessidade de maior atenção, para a questão social do prejuízo individual ou seja dos reflexos comunitários dos danos. Além do mais, para a questão humanista das vítimas e dos estropiados por danos injustos, enfraquecidos e merecedores de atenção por parte do ESTADO, a idéia da culpa presumida já não mais pode se sustentar.

No Brasil, várias foram as tentativas para uma guinada de humanização ou sintonia de nossa legislação civil com a realidade social. ombreando-se, assim, com as dos países mais desenvolvidos. Na década de 40, uma comissão na qual integrava o insigne OROZIMBO NONATO teve o trabalho rejeitado pelo conservadorismo. Nos anos de 60 , outra não menos ilustrada Comissão composta por ORLANDO GOMES, CAIO MARIO DA SILVA PEREIRA e SILVIO MARCONDES chegou a apresentar o seu trabalho, mas teve a proposta retirada pelo Poder Executivo, que a tinha apresentado antes. .. Agora no Projeto 634/75, apresenta-se-nos nova tentativa, que, com evidências, também tem grandes resistências conservadoras.

Não podemos, também, com a opção individualista, continuar tendo a lei civil, com as questões mais importantes, em diplomas esparsos fora da área codificada, pois, na última, não previstas aquelas como «condomínio de edifícios de apartamentos» ou até mesmo a «compra e venda com reserva de domínio», etc. etc.

Não podemos, na matéria indenizatória, continuar com uma orientação de uma pequena e conservadora classe burguesa do século passado, que se esmerou em quase meia centena de artigos dedicados ao 
«regime dotal do casamento» e, outro tanto, dedicado à «questão patrimonial dos tutelados com os tutores», sendo que aquele sempre foi de um desuso incrivel por razões óbvias, enquanto, no último, não se toca quase na particularidade mais importante ou seja a do ser humano tutelado, sua orientação, guarda e educação, uma obrigação primordial do tutor...

A proposta do Proj. 634/75, em matéria da OBRIGAÇÃO DE REPARAR O DANO, substitui com vantagem as particularidades atinentes ao Código de 1916, dentro do seguinte, em sintese:

a) Estabelece, expressamente, como regra geral o direito de reparação pelo puro dano moral, independente de conseqüências materiais; b) Deixa claro parâmetros e restrições econômicas, sociais e de costumes, para o exercício do direito; c) Troca a CULPA PELA CAUSA como ação da pessoa autora e obrigada à indenização; d) Adoção do «risco» nas atividades exercidas como «leitmotiv» de reparação; e) O julgamento indenizatório por equidade, nas dificuldades de mensuração do «quantum»; f) Um novo conceito de ATO ILfCITO; g) Por final, procura dar à vítima de danos a assistência que a legislação atual não pôde dar.

\section{O Ato Prejudicial do Abúlico e Sua obrigação Patrimonial de Indenizar.}

Mudança no particular é o que não falta na proposta do Proj. $634 / 75$, assim como a novidade da obrigatoriedade direta dos menores e amentais promoverem de seus patrimônios a indenização dos seus atos desastrados, cfr. preconiza o art. 930:

«O incapaz responde pelos prejuízos que causar, se as pessoas por ele responsáveis não tiverem obrigação de o fazer ou não dispuserem de meios suficientes».

E, uma vez mais, a troca do pré-requisito da VONTADE EXXISTENTE E ATUANTE pela simples causa e, assim, atinge aqueles que não têm a vontade formada ou perderam-na total, parcial, definitiva ou temporariamente. Tanto evolui, evidentemente, a conceituação clássica absoluta da irresponsabilidade civil dos abúlicos ou incapazes, para a prática de atos com consequiência reparatória na vida civil, pois é cediço que a responsabilidade civil é patrimonial e não pessoal como a criminal.

A leitura do art. 159 do Código de 1916 leva-nos a verificar a exigência da imputabilidade ou livre determinação da vontade, como pressuposto da OBRIGAÇÃO DE REPARAR O DANO INJUSTO, ou seja, a necessidade da capacidade de fato para se ter a responsabilidade civil. Totalmente, dispensável tanto, pois sendo patrimonial e não pessoal são indiferentes aqueles atributos que ornam a pessoa, e, não os seus teres e haveres, para a indenização devida, ou seja a imputabilidade e a capacidade. 
O inolvidável OROZIMBO NONATO em trabalho publicado na R.F. 83/371 «Responsabilidade das pessoas privadas de discernimento» já lamentava o estágio de nossa legislação que é o da responsabilidade da pessoa encarregada da guarda do incapaz (art. 1.521, II), evidentemente até quando se tratava de incapaz com patrimônio e que o pa gamento não lhe retirasse o necessário para a subsistência. Portanto o particular é extrema e nímia justiça, quando afirma no $\S$ único do art. 930 do Projeto:

«A indenização prevista neste artigo, que deverá ser equitativa, não terá lugar se ela privar do necessário o incapaz, ou as pessoas que dele dependem».

o particular da responsabilidade patrimonial do abúlico tem a sua história, estágios e concepções seguintes:

a) No direito romano, comparava-se a ação danosa do louco e suas conseqüências como a excludente do caso fortuito e a respeito de que dizia Ulpiano:

«. . quem viesse a se tornar vítima das ações do louco é como se tivesse danificado por um cataclisma ou pelo vento...»

b) Evoluindo, o ato do mentecapto causando danos estaria necessitando, da autoria, a prova da falta total do discernimento no momento de sua prática (discernimento totalmente ausente ou temporariamente ausente).

c) A par do ônus probandi da autoria surge o direito da vítima de provar que a inconsciência foi provocada, ex: bebidas espirituosas, drogas, falta de cuidados, etc.

d) Surge então no cenário a idéia da responsabilidade do pai, tutor ou curador, conforme o existente em nosso Código de 1916 (1.521). Tal pensamento e convicção tem contra si pelo menos dois sérios particulares: o primeiro a sempre injustiça, quando o abúlico é de grande patrimônio, rico e opulento e o teria preservado, enquanto aquele que por si vela arcaria com os ônus do desfalque; o segundo: a questão de que os atos de magnitude da guarda de incapazes seriam recompensados com o castigo do risco de empobrecimento de inopino dos guardiões (pais, principalmente tutores e curadores), que assim evitariam tais responsabilidades... Nestas condições a lei ao invés de incentivar estaria evitando tais benefícios sociais. . .

e) Finalmente, já consagrada a obrigação de reparar dos incapazes no Código Federal das Obrigações da Suíça (art. 54), no Código Alemão (parágrafo 829), Código Franco Italiano das Obrigações (art. 76), Código do México (art. 1.911), do Peru (art. 1.140), da Venezuela art. 1.187), de Portugal (art. 2.377), da China (Código Civil de 1930: art. 187), do Código das Obrigações da Polônia (art. 134), do Líbano art. 122), Espanha (art. 32), Austria (art. 310), da Itália de 1942 (art. 2.047), da Rússia soviética (art. 406), e outros, e que somente nos 
chega agora na convicção legal da política social de segurança, evitando estabelecer o desequilíbrio social pelo dano, restaurando-se-lhe, se possivel, às custas do próprio patrimônio do autor do dano.

\section{A Presença Maior da Regra da Necessidade da Vítima, diante da Possibilidade Maior ou Menor do Agente do Dano.}

O Proj. 634/75 abraçando a «responsabilidade pelo risco» ou «responsabilidade sem culpa» elege como preocupação maior e primeira a «necessidade da vítima» ao contrário do Código de 1916, que mais se preocupava com o «agente do dano». Trocou-se o «aquele que por ato de vontade causar dano» (art. 159), pelo «haverá obrigação de reparar o dano, quando a atividade desenvolvida implicar risco para os direitos de outrem» (art. 929 § único).

A preocupação que era quanto ao culpado, passa a ser quanto à vítima do dano injusto!

E a proposta insere um julgamento por equidade em casos de ausência de culpa, culpa levíssima ou leve do agente, o que aliada às dificuldades patrimoniais do autor pode levar à redução do «quantum» indenizatório (arts. 964 e 980 em seus $\S \S$ )

«Se houver excessiva desproporção entre a gravidade da culpa e do dano, poderá o Juiz reduzir, equitativamente, a indenização. ( $§$ único do art. 946) ».

$\mathrm{E}$ é evidente que a «socialização ou humanização do direito» não perde de vista também o autor do dano, embora tenha em vista mais os fracos, enfraquecidos e prejudicados. A possibilidade econômica menor do agente, para suportar o peso indenizatório e dar, como conseqüência, uma perspectiva de privação para si e para as pessoas que dele dependem do necessário, faz com que a regra do art. 946 «a indenização mede-se pela extensão do dano» receba vários parâmetros. Além da desproporção da culpa (946), temos a questão da concorrência (947) como a da ausência de querer do art. $930 \S$ único, onde a analogia «ubi eadem ratio, ibi idem ius» poderá levar a regra dedicada aos incapazes, aos também capazes, aproximando-se do princípio dos alimentos do direito de familia como pensionato que a indenização também o é.

A equidade é o ajustamento da regra maior, com o princípio do «summum jus summa injuria» da lógica, e é bastante lembrada no Proj. $634 / 75$, reparando o retrocesso havido com o advento do Código de Processo atual, art. 127). Nossa Legislação processual admite a aplicação da equidade somente quando permitido expressamente pela lei (127), numa revelação do período absolutista em que foi gerado o código processual, quando a regra do de 1939 era mais branda, para a aplicação do solidarismo judicante (114).

A equidade no sentido de adequar a indenização às posses do responsável é um princípio já lembrado e consagrado na maioria dos países 
cultos, atendendo aos princípios fundamentais da responsabilidade civil, conforme afirmativa de Aguiar Dias.

O Código Federal Suíço das Obrigações (1881) em seus arts. 43/4 já nos traz a consagração da equidade e onde vemos o indicador do Juiz, considerando as circunstâncias do caso e dos protagonistas, para a fixação do «quantum», facultando a possibilidade da extensão da obrigação de indenizar.

Evidente que uma indenização não pode provocar um «enriquecimento indevido» (receber a vítima mais do que o necessário para o restabelecimento do «statu quo ante») como também não pode promover um «empobrecimento indevido» (receber a vítima menos do que o preconizado no instituto do «restitutio in integrum»), entretanto o pagamento deverá ter o equilíbrio possível, também para que não se transforme numa injustiça para o devedor.

«Jus est ars boni et aequi» é a máxima seguida pelo direito, destarte a possibilidade menor do agente para suportar o peso indenizatório pode chegar às raias da necessidade da redução, a fim de que não se consubstancie uma outra desgraça ou desastre, ditada aquela diminuição não pela lógica e sim pela equidade (justiça do caso concreto).

O Projeto evolui no particular (aquilo que se tem e aquilo que se deseja ter), de uma maneira das mais justas, visto que a reparação civil é patrimonial, com suas limitações, enquanto, os riscos assumidos por todos, podem causar danos ilimitados, no que concerne às perspectivas e possibilidades da sorte de cada um.

\section{O Autor sem Culpa e o Terceiro Cupado, Mas Não Agente do Dano.}

Se compararmos os artigos 1.519 e 1.520 do Código de 1916. .

... «Se o dono da coisa, no caso do art. $160 \mathrm{n}^{\circ} \mathrm{II}$, não for culpado do perigo, assistir-lhe-á o direito à indenização do prejuízo que sofreu». (1.519)

...«Se perigo ocorrer por culpa de terceiro, contra este ficará com ação regressiva, ao caso do art. $160 \mathrm{n}^{\circ} \mathrm{II}$, o autor do dano. para haver a «importância, que tiver ressarcido ao dono da coisa». (1.520)

...temos com as expressões «dono da coisa», considerando que os danos pessoais não podem intitular-se de «dano na coisa» abandonou o dano pessoal, humano ou físico.

Assim, se alguém causar danos pessoais a outrem, decorrência de culpa de terceiro, o autor imediato terá que promover o ressarcimento à vítima, e, terá ficado sem o direito de regresso contra o autor mediato ou o real culpado, porque a lei simplesmente não lhe teria outorgado referido direito de regresso, quando se tratar de danos físicos, o que é incompreensivel, para uma lei cissil. Seria o primado da matéria sobre o espírito!. . . 
O Projeto Reale faz uma mudança magistral, vejamos... «No caso do art. $188 \mathrm{n}^{\circ}$ II, se o perigo ocorrer por culpa de terceiro, contra este terá o autor do dano ação regressiva para haver a importância a que tiver ressarcido ao lesado». (art. 932)

A troca da expressão «dono da coisa» para simplesmente o «lesado», deixa a idéia espécie e vai à idéia gênero, que contém em si todos os danos, em todas as latitudes, corrigindo não só algo bastante criticável, mas também faz correção de rumo no sentido do social e humano, do reduto do direito individualista e materialista passa-se ao direito social e humanizante.

Poder-se-ia dizer, mesmo pelo entendimento dos arts. 1.519 e 1.520 , aplicando-se a analogia «ubi eadem ratio, idem ius» que chegaríamos ao direito de regresso também para os danos pessoais, entretanto com o disposto no espírito do C.P.C. de 1973, tal ficou difícil e melhor seria que a lei já o trouxesse como agora já se propõe, visto que se trocou «livre convencionamento para decidir» (118) pela «livre apreciação da prova» (131), que nos parece ter restringido a liberdade de julgar da autoridade judiciária.

Pelo menos é um laivo individualista-materialista do Código de 1916, que deixa uma lacuna ou perigosa obscuridade legal e que é procurado corrigir no Projeto 634/75.

Resta, finalmente, com a devida vênia, a expressão «culpa» ou «culpado» que existindo no 1.519 e 1.520 do diploma inserido por Bevilaqua, continua, infelizmente, na proposta da Comissão presidida pelo Prof. Miguel Reale, clamando modificação, visto que, poderemos estar diante do «perigo ocorrido por causa de terceiro» e da «impossibilidade da prova da culpa do terceiro», quando então o autor do dano teria de indenizar e restar-se sem o direito de regresso contra o causador...

Na longa análise, nesses anos de discussão, nenhuma observação foi feita a respeito e, na realidade, tanto vai contra a filosofia do Projeto $634 / 75$, que é de responsabilidade objetiva ou responsabilidade pelo risco criado (causa). Não se justifica a exigência de prova de culpa do responsável pelo perigo, por parte daquele que por azar foi o autor sem o direito de regresso, quando na ação da vítima contra o autor direto do dano basta a causa e não se deslumbra aí uma legal solidariedade passiva. Evidente a falta de equidade de tratamento para o mesmissimo fato, no trato diferente dos personagens.

\section{Responsabilidade do Produtor de Bens de Consumo.}

Em excelente oportunidade, traz-nos o art. 933 do Projeto 634/75, na feição que nos é dada pela Câmara dos Deputados, pois foi ali que surgiu a presente novidade:...

«Ressalvados outros casos previstos em lei especial, os empresários individuais e as empresas respondem pelos danos causados pelos produtos colocados em circulação». (art. 933) 
O Projeto originário não constava tanto e limitava-se à responsabilidade do farmacêutico e empresas farmacêuticas pelos produtos colocados em circulação, solidariamente aos produtores, texto ampliado do art. 1.546 do Código Beviláqua.

A generalização foi iniciativa do Deputado Emanuel Waismann, através da emenda 530, que na oportunidade assim se pronunciou: «. .o consumidor fica abandonado à sua própria sorte, geralmente tido como desonesto em suas transações. Seu cheque não é aceito, suas reclamações não são consideradas. Ao consumidor cabe sempre o ônus dos prejuízos nas compras que realiza, pois não tem onde recorrer.»

O Plenário aceitou a «Emenda» e no relatório geral do Deputado Ernani Satyro, Sua Excia. assim pronunciou-se a respeito: «Colocada nesses termos a questão, atende-se a uma das exigências mais imperiosas de nossa época, indo de encontro aos que se empenham na luta em defesa do consumidor.»

A questão de dispositivos tais na «lei civil» nasceu recentemente em 1977 em Estrasburgo, onde se reuniu o «Conselho da Europa» com uma convenção sobre «Responsabilidade de fato do produtor em casos de lesões corporais ou morte».

A igualdade e nivelamento legal de tratamento entre produtor e consumidor e principalmente a defesa do último é uma luta da qual a codificação civil não pode se omitir, pois, na realidade, naquela sempre tem prevalecido os interesses dos produtores, seja no campo da «culpa privada» seja no da «culpa presumida» pela dificuldades impostas ao consumidor, desprovido de um instrumento eficaz como o que se encontra proposto no Brasil.

Mas produtor não é só aquele que produz ou o autor final, entende-se «todo fabricante de produtos acabados ou de partes e/ou produtos naturais, também aquele que importa ou apresenta como seu, ou o próprio fornecedor, quando não houver identidade do produtor».

Como defeitos dos produtos que podem sequenciar nos danos: «toda falta de segurança, que dele se pode legitimamente esperar, tendo-se em conta as circunstâncias e a apresentação do mesmo produto.»

Tais definições são tomadas da reunião de Estrasburgo do «Conselho da Europa», constantes de ata.

Da maneira que foi ampliada a responsabilidade do produtor tornou o art. 933 do Projeto de transcendental importância e validade social, pois como se vê basta a prova da colocação em circulação do produto, que daí advém a obrigação de reparar, o que tornará os intermediários muito mais diligentes e exigentes quanto às aquisições, promovendo uma segurança maior para o consumidor final.

\section{Os Novos Parâmetros Econômicos e Sociais do Agir Responsável.}

O direito civil com sua milenar autonomia científica e princípios próprios, visando a regulamentação das relações das pessoas, dentro 
de estrita igualdade, é um direito vivo e portanto que muda e altera com as mudanças e alterações dos anseios e necessidades sociais. E tais mudanças de pensamento e ideal social são na maioria ditadas pelo próprio progresso tecnológico.

E os progressos são quase sempre resultado de problemas antepostos e desafiadores da inteligência e perspicácia do homem, como se eles, os problemas, fossem para o próprio desenvolvimento uma necessidade, ou, quase uma causa os primeiros e os últimos um efeito da causa.

Vivendo sem guerra, grandes desastres e inquietações, a pequena e conservadora sociedade burguesa que liderava a vida brasileira no século XIX, dentro do provincianismo e academicismo da «belle epoque», somente poderia nos outorgar uma legislação codificada que tudo aquilo refletisse como bem o fez.

Lembremo-nos que foi em 1899 ( o fechar das luzes do século passado) que o governo de Campos Salles entregou a Clóvis Bevilaqua o encargo de apresentar um projeto de Código Civil; portanto, foi com a experiência voltada para os anos anteriores o espírito da codificação e a maneira com que o jurista deitou mãos à obra. Tanto já tinha em mente a estrutura e as idéias, que em poucos meses entregou o notável trabalho, calcado em uma estrutura já existente.

E o espírito da codificação preocupou-se mais com a defesa do patrimônio material, fato que se revela no instituto da tutela, quando se dedica quase meia centena de artigos à defesa patrimonial e quase nada com referência às obrigações do tutor quanto à educação e a construção do ser humano tutelado (418). Exagera-se na atenção ao regime dotal do casamento (278), quando tal espécie além de escassa, antes e depois, coloca um patrimônio garantidor da estabilidade da união, quase que substituindo o sentimento maior do amor e do entendimento. 'É de uma característica individualista, sem dúvida, nosso diploma de 1916, tão individualista que se olvidam institutos já existentes como «condomínio em edifícios de apartamentos» e outros como o da «compra e venda com reserva de domínio», etc.

Mas as possibilidades e as excelências do diploma civil são maiores do que suas negatividades e falhas, entretanto a questão não é de se julgar bom ou mau, de mérito ou demérito, é da necessidade de rompermos com o «direito individualista» que ele encarna em suas páginas, quando tudo direito social».

O nosso mundo é o das idéias e do espírito. O homem de letras, num País ainda não desenvolvido, não pode ser fútil e irresponsável, tem de ser criativo e lutador, pois tem compromisso com o «fazer social». Para os juristas o «fazer social» é o «fazer justiça», logo estamos comprometidos com tudo que é luta contra a injustiça, principalmente com a luta contra a irresponsabilidade dos que deveriam ser os mais responsáveis, dando à maioria uma falta de segurança, que diminui, estrangula e retarda. 
As modificações legais de cunho social não só constituem uma necessidade, como também um dever da classe jurídica pois um anseio de todos de maior justiça, de maior equidade entre patrimônios materiais e responsabilidade civil, que devem estar em razão direta e não em sentido diverso.

\section{O Novo Conceito de Cumprimento de Obrigacão e a Dívida de Valor e Não de Dinheiro.}

Diante de que, após o julgamento e liquidação da lide indenizatória, é perfeitamente possível não só a alteração da situação econômica dos participantes da relação indenizatória ou mesmo o agravamento, amenização, aumento ou diminuição da extensão do dano, temos que admitir algo como o «direito de revisão das indenizações».

É uma questão de nímia justiça, da mesma forma preconiza para os alimentos do direito de família, visto que as sequelas do dano podem aumentá-lo ou diminuí-lo, imprevisivelmente, após a própria liquidação da ação reparatória. Ora, se o parâmetro indenizatório, também para os danos pessoais, é a extensão do prejuízo e se o mesmo pode alterar-se com o tempo, a conclusão é de que aumentando-se a dimensão, a justiça feita passa a não ser justiça realizada que é a do «restituitio in integrum».

Tanto é de ser deduzido do próprio art. 946, quando afirma que «a indenização mede-se pela extensão do dano». A questão toma importância maior com os danos físicos (remediáveis ou irremediáveis), pois ligados à vida, que tem como próprio de si as mudanças, transformações e movimento.

$\mathrm{Na}$ indenização quando se trata de prestações periódicas ou prestações pensionadas e a vítima pensionista a possibilidade de revisão é patente, possível e legal, expressa mesmo no $\S 3^{\circ}$ do art. 602 d C.P.C., daí podermos acreditar que a obrigação de reparar não transita em julgado, visto a possibilidade futura de agravamento ou amenização do dano, por razão idêntica do permissivo da modificação da situação econômica dos litigantes. Ocorre que nos traz o Proj. 634/75 a novidade do art. 952 «in fine».

«... O prejudicado, se preferir, poderá exigir que a indenização seja arbitrada e paga de uma só vez!»

Assim, pergunta-se, no particular, se ainda persistiria a ausência do trânsito em julgado, pois não deixaram de ser pensão pagas de pronto, de uma só vez. «Ubi eadem ratio, ibi idem ius»...

O raciocínio seria então: havendo o permissivo legal para redução ou aumento nas prestações ( $\S 3^{\circ}$ do art. 602 do C.P.C.), quando há a mudança nas condições econômicas, também quando há o agravamento ou minoração do dano físico que até pode passar de categoria remediável para irremediável ou vice-versa, pela mesma razão, poderá haver a alteração. Razão analógica! 
Assim, também pela admissível e possível mudança do «quantum» pensionato, poderiamos chegar, na busca do «direito de revisão da condenação», ao direito do autor do dano de reclamar indenização de diferença a maior ou cuja margem deixou de ser um retorno ao «status quo», para ser um «benefício para o queixoso», quando por exemplo a lesão já desapareceu há muito e ainda as prestações continuaram a ser pagas, ou para quando o trabalho que se inabilitou a vítima já tenha reconquistado a habilitação plena.

Como vemos o conceito de cumprir obrigação reparatória é altamente elástico, tornando difícil o conjugar do verbo no passado, diante das questões ora colocadas e outras mais.

Por final, a correção monetária transformou-se na escala de valores, não num novo instituto, mas sim numa essencialidade indisponivel.

Plenamente admissível segue a mesma linha de raciocínio protetivo dos valores perdidos com o dano, substituindo para sempre, numa estrutura inflacionária, a «dívida de dinheiro nominalizado», que é impossível de ser aceita como pagamento havendo a diferença cronológica entre o termo da constituição da obrigação e o termo do pagamento. É uma homenagem ao instituto do «restitutio in integrum» como o é da mesma forma a mencionada possibilidade da revisão das pensões reparatórias.

\section{A Gravidade do Ato e a Não Extensão do Dano Como Medida Indenizatória.}

É uma flexibilidade do Proj. 63 a regra geral encontrada no § único do art. 946, onde ao invés da indenização pela extensão do dano, temos: a indenização do prejuízo pela intensidade da culpa do autor do dano ou o julgar pela equidade, reduzindo o «quantum» indenizatório.

«Se houver excessiva desproporção entre a gravidade da culpa e o dano, poderá o juiz reduzir, equitativamente, a indenização».

Tal inciso foi bastante discutido na Câmara dos Deputados pelos Deputados Tancredo Neves, Cleverson Teixeira, Siqueira Campos, Fernando Cunha e outros com cerca de 5 (cinco) emendas. S. Exa., que depois foi guindado à Presidência da República, firmou: «a indenização deve ser plena, de modo a propiciar a integral reparação do prejuízo» (emenda 539), enquanto os demais foram para que não se desse «aos juízes tamanha atribuição de alcance impressionante» conforme expressão de um deles, enquanto outro dizia;» o perigo está em que há juízes bons, integros e ilustres, mas há também os maus, perseguidores e grosseiramente incultos», todos batendo na tecla da supressão daquele dispositivo.

Olvidaram suas Excelências que o juiz não é instância única $e$, por outro lado, não se legisla pelos possíveis erros e defeitos dos aplicadores e sim pela justiça, lógica e humanização da norma. 
No sentido contrário, ou seja, no sentido de se ampliar o «reduzir» para «fixar» firmou-se o Deputado José Bonifácio Neto.

O Relator Geral, Dep. Ernani Satyro, recusou todas as emendas, com apoio do Plenário. Com referência à proposta de substituição do termo «reduzir» para «fixar» expressou-se: «O poder que no mencionado parágrafo se outorga ao juiz é apenas o de reduzir a indenização por equidade, se verificada excessiva desproporção entre a gravidade da culpa e o dano».

Realmente o «fixar» que poderia ser também «aumentar» iria ferir o «restitutio in integrum» e transformar o dispositivo em uma apenação não razoável.

O princípio da «redução» por equidade, decorrente das condições econômicas do responsável, já está exitoso em países evoluídos. Uma desgraça não se compensa com outra, ademais quando em se tratando da intensidade leve da culpa, até o homem cauteloso pode incorrer (levíssima) ou o homem médio pode incidir (leve) e sempre somente o querer-meio ser a força-motriz.

\section{O Puro Dano Indenizável por Equidade.}

Quando se vê que ainda há resistências contra a convicção e a possibilidade da indenização do dano moral, fica perdido um alto sentido social do direito pátrio, mostrando-se incapaz de proteger os valores da afeição e imateriais somente pela dificuldade da mensuração econômica.

«Nestes casos não há necessidade de satisfação pecuniária. Todavia não tem faltado quem queira reduzir o simples sofrimento físico ou moral a valor: São extravagâncias do espírito humano. LAFAIETE in «Direito das Coisas» - $3^{\text {a }}$ Ed. $\S 205$ nota 8».

Palavras tais e de tamanha autoridade fizeram escola e discípulos na doutrina e principalmente na jurisprudência, como o impulso conservador, que pode provocar o subdesenvolvimento e o atraso. Até os romanos, apesar das discussões já existentes, possuíam a «actio injuriarum aestimatoria» e «in bonum et aequum conceptae», reconhecendo a justeza da indenização material de danos de natureza não econômica e material, entretanto após milênios estaríamos a persistir no sentido da negação da evidência daquele justo e possível.

A expressão «homo homini lupus» (Hobbes) faz-nos crer que a crença da não indenização dos danos morais faz o incentivo e a explosão do lobo, dando a insegurança e intranqüilidade torpedeadora do progresso social.

No Brasil, Clóvis, Filadelfo Azevedo, Pontes de Miranda, Pedro Lessa, Orozimbo Nonato, Aguiar Dias e tantos ou lutaram e lutam para fazer do direito uma força evolutiva e social espancando os argumentos 
dos que litigam contra a indenização do dano moral. O próprio diploma de 1916 mostra nos arts. 76 (interesse moral), 1.543 (valor de afeição), 1.547 (injúria) e 1.548 (honra da mulher) o seu sentido de reconhecimento, enquanto no mesmo diploma o art. 1.537 (homicídio) mostra a outra face da moeda, a do não reconhecimento. . .

Lamentável a timidez, pois negando ou dificultando a reparação dos danos morais injustos, contesta a existência da parte ética do homem como patrimônio de valor, num autêntico materialismo.

A dor e a emoção constituem o patrimônio ideal ferido que prepondera mais do que o patrimônio material desfalcado, pois atinge, diretamente, o coração e os sentimentos do homem, exatamente aquilo que o diferencia das coisas.

A alegada dificuldade de mensuração econômica, o convencionado e único denominador de valores: o dinheiro, não pode chegar a negar o principal que é a injustiça do fato, ou seja o prejuízo moral havido. Que se meça e que se estime deficientemente, pois é preferivel enfrentar com coragem tal deficiência do que se negar a reconhecer juridicamente o prejuízo que não se conseguiu bem medir, portanto pela lógica bem existente...

No particular o Proj. 634/75 foi claro no art. 186...

«Aquele que por ação ou omissão voluntária, negligência ou imprudência, violar direito e causar prejuízo a outrem, AINDA QUE EXCLUSIVAMENTE MORAL, comete ato ilícito.

$\mathrm{E}$ tal pensamento dos projetistas continuou... Se este não puder provar prejuízo material, caberá ao juiz fixar, equitativamente, o valor da indenização, de conformidade com as «circunstâncias do caso.» ( $§$ único do art. 955 do Projeto 634/75) ».

Reconhecendo aí o dano moral e o seu direito, efetividade e equitatividade na reparação, quando o art. 1.547 do diploma de 1916 remetia para o «valor da multa ao grau máximo da pena criminal respectiva».

A questão que era simbólica (reparação) e jungida a um parâmetro administrativo (multa penal), transmuda-se para um julgamento por equidade, significando grande avanço de técnica legislativa, confiando na perspicácia do julgador, diante da vítima e sua dor.

\section{A Ofensa Aos Direitos da Personalidade e os Cálculos Indenizatórios.}

Uma das grandes novidades do Proj. 634/75 é sem dúvida o capítulo «Dos Direitos da Personalidade», cujas características são: individualidade, indisponibilidade e imprescritibilidade. Dir-se-ia que são os direitos individuais físicos: à vida, ao corpo e ao cadáver; como os direitos individuais morais à honra, liberdade, recato, imagem educação e proteção. 
Se verdade é que a pessoa adquire a personalidade no nascimento e perde-a com a morte, ou seja coincide a existência da pessoa com a sua personalidade, temos exceções seja, antes, com «os direitos do nascituro» seja, após, sobre o despojo do corpo humano, ou a obra literária deixada. Verdade é que os direitos civis da personalidade existem e precisam ser melhor fixados, delimitados e respeitados. Longe do liberalismo romântico do Século XVIII surgem os «direitos da personalidade» como uma necessidade para a defesa da própria essência humana, sem o que o homem passaria a ser coisa, dentro do avanço tecnológico.

$\mathrm{E}$ tais direitos podem ser ofendidos e, se tanto, objetos de busca de reparações. O Proj. 634/75 não descurou do assunto e nos arts. 955/956 trata dos danos morais (injúria e calúnia) autorizando o julgamento por equidade e estendendo-se à liberdade pessoal, dentro das mesmas conclusões.

O particular passou sem emendas na Câmara dos Deputados e o contributo novo, que se notou no trabalho dirigido pelo Prof. Miguel Reale foi: $1^{\circ}$ ) A troca dos parâmetros indenizatórios até então jungidos aos valores das multas criminais, para a decisão equitativa de valoração: $2^{\circ}$ ) $\mathrm{O}$ abandono da obrigatoriedade única de quem ordenou a prisão ilegal (art. 1.552 no Código de 1916), tornando solidário mentores e executores; $3^{\circ}$ ) O reconhecimento da possibilidade indenizatória por todos danos morais (186), onde, evidentemente, ficam residindo os «direitos da personalidade» (vida, honra, privatividade, dignidade física e psíquica idéias, liberdade, etc.) sujeitos às decisões reparatórias por equidade. Um notável progresso, sem dúvida!

A elasticidade dos «direitos da personalidade», pois, inerentes aos atributos da pessoa humana, partindo do direito à vida e à liberdade, chega-nos com a defesa da vida a questões altamente discutiveis que podem ser a da existência de uma qualidade de vida artificial ou inexistência de vida artificial ou inexistência de vida natural, mantida aquela através do funcionamento de órgãos humanos por medicamentos ou máquinas, em pacientes terminais desenganados ou incuráveis.

A nossa sociedade educou-nos para negar a morte e em decorrência de tanto a questão fica polêmica, quando se discute a eutanásia como intromissão do homem no tempo de vida natural do próprio homem, ao lado da questão de desligar as máquinas, o que não é interromper, mas sim deixar de prolongar uma vida meramente artificial.

Provocar a morte por meios diretos, sim é um crime, mas não podemos chamar tanto quando se suspende ou deixa de ser ministrada medicação ou instrumento mecânico, que somente conserva a vida por tempo determinado (a eutanásia falsa e indireta). Tal atitude talvez fosse a mesma do direito da personalidade à uma vida natural com dignidade ou o direito a não se ter uma vida artificial definitiva $e$ vegetativa. 
Sem o menor vislumbre de sucesso médico, de utilidade e eficácia na busca da vida e saúde do paciente, surge, por parte do profissional médico, a obrigação de colocar a família, totalmente, a par para decidir, visto que a partir daí poderemos ter ou a vaidade de uma luta inglória ou o amor - homenagem afetiva - ao ser humano moribundo, nada mais, e, tudo mantid o pel o engenharia médica ou a medicação de conservação determinada e limitada.

Não cumprindo esse dever de verdade, fica um ato ilícito do profissional da medicina ou o risco profissional do mesmo, o que poderia promover sérios danos materiais e morais ao grupo familiar, de maneira injusta, podendo no futuro serem enquadrados como reparáveis e indenizáveis os gastos, despesas e honorários ou contas milionárias desnecessárias.

Vê-se, assim, que há um problema jurídico presente nas U.T.I.(s) dos hospitais com uma possivel latente obrigação de «não fazer», quando total e sabidamente inútil se apresentam os esforços de saúde e retomada da vida natural. Referida questão não foi levantada pela Comissão, nem está na redação definitiva da Câmara, entretanto não ficará a ausência por muito tempo, pois se trata de uma necessidade da própria classe médica no dilema: se desligar estaria sujeita até mesmo a apenação criminal, se não desligar estaria também cometendo um ilicito com o desenvolvimento de trabalho sabidamente inútil por vaidade ou satisfazendo vaidades ou ainda por uma atitude de respeito, mas que seria uma estranha reverência, exigindo sofrimento desnecessário do reverenciado paciente. . .

Quando se vê que grupos familiares gastam o que têm e o que não têm com os altos custos dos pacientes terminais, uma discussão é de ser dita: até onde seria lícito exigir tamanhos sofrimentos e tamanhos gastos, quando já se os sabia inúteis, definitivamente inúteis pela própria ciência médica???

A questão que fica é: Sugere-se que no final do art. 953 acrescente-se:

«. .ou pelo tratamento causar-lhe ou a terceiro injustos prejuizos».

\section{A Queda do Subjetivismo e Individualismo na Noção de Culpa, Diante da Ascensão do Objetivismo e do Direito Social na Noção de Mera Causa.}

Quando se fazem dois (2) círculos concêntricos um menor do que o último (o maior) de causa, torna-se fácil entender que tudo que é culpa contém-se dentro e no interior da causa, enquanto nem tudo que é causa é culpa.

Assim, a «teoria da causa-responsabilidade objetiva» contém dentro de si a «teoria da culpa-responsabilidade subjetiva» e esta deixa de conter extensa faixa da primeira. Conclusão: a busca (maior) é 
mais viável quanto ao êxito do que a busca da culpa (menor) assim ilógico e desumano apego à teoria da «culpa-responsabilidade subjetiva».

A questão não é nova e desde a metade do século XIX está sendo agitada, com o surgimento da escola positiva penal, onde a pena deixa de ter em primeiro lugar o autor do crime, para ter em consideração primacial a sociedade (Ferri e Binding); alí representada pela vítima do dano injusto.

A sociedade, ferida e desequilibrada com a agressão cometida, exigindo a reparação indenizatória. Seria a mera necessidade da vítima diante do fato jurídico ou acontecimento que produziu o dano injusto, e, não como na escola clássica onde há a necessidade de se provar um ato de vontade do autor (responsabilidade subjetiva).

Tanto afasta o fantasma da prova da culpa, com dificuldades mil, como uma mensagem destinada a camuflar a própria verdade dos fatos, pois a psicologia diz-nos da impossibilidade da prova provada inconteste da culpa!

A questão não deixou ter a influência da revolução industrial com a surginte maquinaria, quando perguntava-se: «... e o dano causado pela máquina, que não tem vontade???»

Os jusnaturalistas tentaram justificar tanto como «acts of God», força maior, etc., o que não satisfaz aos ideais de justiça dos dias atuais...

Se admitido tanto (responsabilidade subjetiva), na realidade teremos a «irresponsabilidade como regra e a responsabilidade como exceção da regra», pois o grande contingente de atos danosos ficarão protegidos pelo manto da culpa, enquanto somente uma pequena parcela ficará sujeita aos ressarcimentos. O pior de tudo é que a experiência nos tem mostrado que no maior e protegido contingente, ficam os que possuem mais, e no menos protegido contingente, os que possuem menos. . .

A «teoria do risco proveito» ou a «teoria do risco criado» fixa a derrocada do subjetivismo e individualismo, extinguindo o direito individual absoluto, que fazia acreditar no: «aquele que age dentro do seu direito a ninguém prejudica», negando a possibilidade do abuso do direito, ou da função social do direito «nemine laedit qui sou jure utitur».

A «teoria do risco» embasa-se em lições do direito romano com o princípio do «ubi emolumentum ibi onus», ou seja: onde a busca do lucro aí os riscos inerentes a tanto!

Poderiamos até dizer que aqui (responsabilidade objetiva) não se busca o moralmente responsável ou a busca da consciência, mas da constatação do prejuízo injusto para alguém, que irresignado pede a recomposição, a justiça de intervenção do Estado, cuja ausência ou 
omissão seria a negação do papel maior que é o de dar proteção e segurança aos jurisdicionados.

A questão não é de responsabilidade como o somatório jurídico dos conceitos de imputabilidade e capacidade, conhecido na lei, e, sim, da responsabilidade como simples obrigação de reparar. E fica entendida quando imaginamos o causador de dano em si próprio, onde não deixa de ser responsável, mas não terá obrigação de reparar, pois aqui temos a figura da «confusão», enquanto ao caso do pai pelos atos do filho teríamos a obrigação de reparar, mas poderíamos não encontrar a responsabilidade-imputabilidade pelo ato, naquele pai.

A expressão de Rudol Von Ihering «sem culpa nenhuma reparação!» é de um individualismo correspondente à época em que foi pronunciada, hoje a «responsabilidade pelo dano» faz nos abraçar o direito social, o solidarismo, onde o causador deve indenizar pelo simples fato e não pela vontade, que não interessa existente ou não, para a existência do dano, que continua o mesmo com ou sem ela...

Assim é alvissareiro o Proj. 634/75 no particular de seu art. 929 $\S$ único e outros, adotando e inovando com a «teoria do risco - responsabilidade sem culpa», ombreando o nosso direito com os mais evoluidos dos paises mais adiantados.

\section{A Responsabilidade do Estado.}

A expressão «responsabilidade civil do Estado» talvez promova um erro crasso, pois o Estado reside no Direito Administrativo e não no Direito Civil. Se erro é, o Código de 1916 cometeu-o, quando o art. 15 menciona a mesma.

A obrigação do Estado é a de reparar, obrigação de indenizar, nos mesmos moldes civis, entretanto civil não o é, e, sim, administrativa, com outra espécie do gênero «reparação do dano».

Entretanto, a expressão «responsabilidade civil» é quase universal e continua a ser repetida no Proj. 634/75 em seu art. 43:

«As pessoas jurídicas de direito público (inseriu a Câmara aqui a expressão «interno») são civilmente responsáveis por atos seus agentes que nessa qualidade causem danos a terceiros, ressalvado o direito regressivo contra os causadores do dano, se houver por parte destes, culpa ou dolo».

O anteprojeto da Comissão que foi cópia fiel do Código de 1916 teve uma modificação por parte do Poder Executivo, que consumiu a expressão: «procedendo de modo contrário ao direito ou faltando com o dever prescrito por lei».

$\mathrm{E}$ tanto foi interessante, porque se parecido com redundância a expressão acima, comparada com «causar danos a terceiro», visto que tal procedimento só pode ser procedimento contrário ao direito ou falta 
do dever legal, a amputação teve amplitude maior, pois realçou como fato único o «causar danos a terceiro» e deixou o aspecto da negligência quanto ao direito ou a imprudência, quanto também ao dever legal, que são subespécies da culpa.

Repete o art. 43 do Projeto a exaustão o que contém o art. 107 da Constituição de 1969 (Direito Administrativo), mudando o seguinte com referência à lei civil atual: Basta o agente causar dano a terceiro, enquanto presente (lei civil) tem-se a necessidade da negligência $e$ imprudência como pré-requisitos.

Outra questão digna de nota foi a mudança do «direito de regresso» que no Código é «por ter causado dano» (art. 15), enquanto no Projeto é: «se houverem agido com culpa ou dolo», portanto o «direito de regresso», que era objetivo passou a ter o substrato subjetivo, numa humanização do texto, para com a parte economicamente fraca dos funcionários públicos, que quase sempre cumprem ordens.

Assim, a proposta do Projeto 634 apregoa a «teoria do risco», humaniza, atualiza e socializa o direito civil pátrio; portanto deverá sofrer ainda sérias restrições dos conservadores. 